\title{
THE AIMS OF INITIATION CEREMONIES AT UNIVERSITIES: COMPARISONS IN TIME AND SPACE 1
}

\author{
N.S. Jansen van Rensburg \\ Department of Anthropology \\ Potchefstroom University for CHE \\ POTCHEFSTROOM
}

\begin{abstract}
In this article initiation practices at South African universities are anabysed and compared with initiatlon ceremonies described in anthropological literature. It is argued that any initiation ceremony has at least the partial aim of preparing initiates for the roles and functions in sociery or specific organizations. Naturally a reasonable degree of harmony between the intent of initiation on the one hand and the values of an institution on the other hand can be expected. The intention of initiation usually is to prepare one for a position or role by means of the expression of cenain values. On the question whether this harmony between ideas and actions is found in the case of existent initiation ceremonies at South African universities, the answer is negative. These ceremonies do not aim to convey and develop antitudes and values essential to a university and in fact do not prepare first-year students for their new environment and a community of scholars. The way in which universities transcend their authority by condoning and officially allowing the demeaning initiation practices is also questioned.
\end{abstract}

\section{INTRODUCTION}

In this article it is argued that the persistence of initiation practices at some South African universities is representative of resistance to societal change in general. Furthermore, these practices are foreign to the values which ought to be inculcated by the university and academic scholarship and training. They serve the purpose of assimilating students into an artificial community life, which insulates them from the claims of academia and the wider society of which the university is a part.

\footnotetext{
${ }^{1}$ A draft of this article was presented at a conference of the Association for Anthropology in Southern Africa during September 1989 at the University of the Western Cape, Bellville. I want to acknowledge the advice received from prof. M. Elaine Botha, regarding the improvement of the initial draft of the paper. The paper formed a theoretical base for a planned empirical study, which has not been completed due to impediments created by certain interest groups. The financial support of the Research Committec, Faculty of Arts, PU for CHE, is acknowledged.
} 
With this in mind, a survey is made of some literature on initiation ceremonies ${ }^{2}$ to ascertain the most important aims communities have with these ceremonies. These ceremonies are sometimes closely linked to the interpretation of every community on the positions and statuses that initiates will take up in society or a specific organization. Therefore, initiation will probably at least partially have the aim of preparing 3 initiates for these roles and functions in society or for roles and functions in specific organizations. These ceremonies require proof of ability and endurance which separates the social life of adults/members and children/novices. The question can be posed whether these aims and intentions which are expressed by societies or groups, harmonize with or conform to the type of actions which are found in initiation ceremonies and whether they are effective.

One can expect a reasonable degree of harmony or conformity between the ideas (rules/ intent) regarding initiation on the one hand and actions (ceremonies) in a society or organization on the other hand. The social values of a community will probably also be expressed and maintained by initiation ceremonies and the symbols inherent to this drama. If this were not the case, initiation will probably become completely senseless 4 . Although many ethnographies do not provide this specific kind of information, one can still assume that the intention with initiation will still be to prepare one for a position or role in society by means of the expression of certain values. Although ritual is the expression of ideas and social meaning, it can also be seen as effective action 5 .

\footnotetext{
2 Although my aim is not to do a critique of literature on initiation, the impression intensified, as I progressed, that the interpretations of many writers on initiation ceremonies and the aims societies have with them, should in fact be regarded with a fair amount of scepticism. In this discussion the material and interpretations (mainly functionalist and symbolist) of the authors are provisionally used as they are given.

3 According to Vizedom (1976:15) Radcliffe-Brown, put succinctly, saw the function of ritual as indoctrination; cf. also Richards, 1956:53-54.

4 La Fontaine's (1985:13;35) self-admitted "circular" argument is "... the ritual action whose essential quality is that it constitutes a sequence which accomplishes a purpose ... and ... the participants believe that they are accomplishing their aim in what they do."

5 La Fontaine (1985:184) is of the opinion that: "Whether it is the material world that is to be affected ... or human beings who are to be redistributed among the groups and positions that make up social life, ritual is expected to produce results"; cf. also Richards, 1956:113: "... rites are ... invariably an effort to 'do'." Lincoln (1981:108) on the other hand, sees the sense of meaning as the greatest benefit of ritual.
} 
The question can then be put as to whether this reasonable degree of harmony between ideas and actions is found in the case of existent initiation ceremonies at universities. Do initiation ceremonies (orientation) which are performed by students at some universities, have a positive relationship with the basic ideals of a university and of the society within which a university functions? The answers to these questions would be negative.

\section{INITLATION AS PREPARATION FOR LIFE IN SOCIETY}

\subsection{Transition and transformation}

The general view of initiation (as a rite of passage) is that it usually has the function of passing initiates from one state or status to another and of the transformation of the individual [the creation of "men" and "women"] ${ }^{6}$ and by this actually make a contribution to the life of society. A more dynamic approach may be that initiation ceremonies in general "... address themselves to a tension between the changes inherent in the life of an individual human being and the relative stability of society, which frequently finds expression in a conflict of interest among members of different generations" (Vizedom, 1976:19). This does not imply, however, that rites in general or initiation rites have an all-encompassing explanatory or functional meaning. The reason for this is mainly because the correlation between rites of passage and change has not been supported by ethnographic evidence (Vizedom, 1976:20-22). The limitations of a simple functionalist explanation (and other partial explanations) are generally acknowledged (Keesing. 1981:20-39).

Although the transformation of individuals is a demonstration of the power of ritual knowledge as experienced by the initiates and other participants alike, initiation also clearly supports the position of those in authority. According to La Fontaine (1985:104) the individuals "... are, to this extent, objects used in the ritual, rather than its central focus through which the ritual is to be explained".

If Vizedom's (1976:24) summary of the views of the functions of rites of passage were accepted, the approach in this discussion would probably be the closest to the one

\footnotetext{
6 Winick, 1957:287; Zietsman, 1972:159; Lincoln, 1981:94-95; La Fontaine (1985:179) sees initiation as "... a patterned performance whose purpose is action to achieve transformed individuals but whose effect is to demonstrale the power of traditional knowledge and legitimize a continuing social order."; cf. also Van Gennep, 1960:3. This characleristic of formal status change does not apply to groups such as the Bau A (Schieffelin, 1981:195); Keesing, 1981:8.
} 
which she calls "role assumption in typical life span"; the concern with "cultural definitions of persons in society" and "the significance of the rite in an on-going irreversible change in a person's life". This does not exclude the very real existence of control and physical and psychological dominance of juniors by seniors or women by men, as indicated for some areas (Keesing, 1981:26 et seq).

In the following sections some characteristics which have the purpose of preparing initiates will be summarized, with a view to later application.

\subsection{Liminality}

According to Arnold van Gennep's classic argument, all rites of passage changing an individual's social status, conform to one basic pattern, namely a three-stage pattern whereby one is separated from one's previous environment; spends a period of time in limbo (liminal or transition rites); and assumes a new station in life (rites of reincorporation) ${ }^{7}$ (Van Gennep, 1960; cf. also Lincoln, 1981:99; Van der Vliet, 1974:229). The liminal period is an important phase for the instruction and preparation of the initiate.

Initiates are expected to perform actions which are strange or foreign to human beings during the period of liminality such as eating or otherwise acting as an animal (Richards, 1956:64). Sometimes wild behaviour is allowed and violent emotion may even be fostered or approved of. "This may be seen as evidence of a single-minded violent drive to be initiated, but they also describe the novices as wild, and the novices are not held accountable for things they may do in this state. To the observer they appear to be giving an impression of untamed humanity, outside normal society; they are powerful but asocial" (La Fontaine, 1985:122). So, for instance "A ritual is performed to accomplish socially defined purposes; the licentious behaviour of women is part of a sequence of actions which are believed to achieve it" (La Fontaine, 1985:165).

\footnotetext{
${ }^{7}$ It is important of course, to realize that even so-called abnormal behaviour, may not necessarily be rebellious in nature, but forms part of expected role playing.
} 


\section{Tests and ordeals}

The physical and emotional tests (Richards, 1956:66,67,70) and ordeals found in initiation ceremonies usually measure the initiate's fitness to enter his/her new status. The elders usually arrange and handle the ceremonies and because they are usually mandatory, not going through the rites may mean disgrace (Winick, 1957:287; Herdt, 1981:76; Van der Vliet, 1974:230). If initiates do not abide by the rules laid down, physical punishment of a more or less severe nature may result (La Fontaine, 1985:157. 8; Newman \& Boyd, 1981:252). These ordeals simultaneously test the qualities (to conquer fear or maintain self-control) of the candidates and provide an essential element of the whole experience which effects the change in them. The initiates may sometimes be frightened, taunted, treated with disgust and indignation and treated as if they were irresponsible and troublesome, told that they are soon to be killed, are beaten or subjected to lewd joking and the initiators in some cases take an almost cruel delight in the embarrassment of the initiates (in this case boys), knowing full well that it would soon be transformed into one of terror. In some recorded instances, the officiants carefully watch so that ritual ordeals do not exceed what the initiates can endure (Zietsman, 1972:190-1; La Fontaine, 1985:16,121,122,186; Herdt, 1981:59,63,64; Poole, 1981:120-123,137; Schieffelin, 1981:185; Newman \& Boyd, 1981:252,283; Tuzin, 1981:340). One specific case described by the author as an embodiment of terrorism, has the intention to "subdue the novices through an act of raw dominance" (Tuzin, 1981:341).

\subsection{Instruction and authority}

Specialized instruction (in which knowledge and moulding of character is included) is usually an important part of initiation ceremonies (Hays \& Hays, 1982:219; Newman \& Boyd, 1982:265-70,272,273,280). Instruction can have the aim of indicating the position of initiates in the structure and enforcing respectful behaviour to seniors (or men) who are displayed in a position of power and authority. It usually also conveys to the initiates what is regarded as good behaviour or what they can expect in life ${ }^{8}$. The initiates acquire certain rights but this also entails duties, of which one of the most important is that of obedience to seniors. Especially in the case of initiation into secret societies, "... the ritual itself associates the authority and status of officiants with knowledge and this appears as the basis of their authority" (La Fontaine, 1985:169,174,

${ }^{8}$ Cf. Poole, 1981:137; "If the husband commits adultery, she may say nothing about it" (Richards,1956:71;86;88); Van der Vliet, 1976:240. 
quotation on 187,188; Zietsman, 1972:329; Lincoln, 1981:21; Van der Vliet, 1976:231). In some cases, the initiates have already long since mastered the skills their teachers mockingly demonstrate. The "children", however, are not allowed to display their ability publicly and " $(t)$ he teachers' mode of instruction is, in this sense, sarcastic, for it ridicules the very behavior toward which the initiates strive" (Gewertz, 1981:293).

During initiation, anxiety caused by stress induces increased suggestibility, which allows for attitudes to be changed or values reinforced ${ }^{9}$ (Winick, 1957:287; Zietsman, 1972:187-8; La Fontaine, 1985:158). In some cases the "moral evil of the initiand's former life is removed" in the ritual and the advantages and pleasures of membership is emphasized (La Fontaine, 1985:65).

Preparation of initiates can be both mystical and pragmatic and can demonstrate the relationship between the roles of individuals or can describe and evaluate behaviour. Furthermore " $(t)$ he whole corpus of ideas evoked in ritual is the traditional knowledge of society ... expressed and put to use" (La Fontaine, 1985:14).

Restrictions may also be placed on the young person. This enables the older men (or women) to retain their power and influence and prevents the initiates in "getting above themselves" as they cannot be regarded as full members until they have passed their trials (Davies, 1972:102; Turnbull, 1976:57;154-155). These restrictions may be related to contact with women, food, special clothing or lack of clothing (La Fontaine, 1985:139,168; Lincoln, 1981:103; Newman \& Boyd, 1981:265,269; Gewertz, 1981:293).

Resulting from this, there is a kind of pretence that the society controls natural processes, a cognitive usurpation extending the already extensive control by the community over the lives of individuals (Vizedom, 1976:38). The attainment of control is also expressed by interpreting all new events as repetitions of the past, with all eventualities already accounted for by putting an appearance of synchrony on diachronic events (Levi-Strauss, 1966:235 as quoted by Vizedom, 1976:38) and asserts the authority of tradition and its carriers. In one case the elders maintained that the essentials of sacred tradition were created and formulated by primordial ancestors in terms that are difficult for mortals to comprehend (Poole, 1981:110).

The indications regarding the interlocking and supporting function of instruction and authority are so clear in initiation ceremonies that Vizedom (1976:38; cf. also Keesing, 1981:16) comes to the following conclusion: "Just how far the control by the normative

\footnotetext{
A process similar to brain-washing is described by La Fontaine; cf. also Herdt. 1981:76.
} 
order, this cultural bribe, may be carried is apparent in the frequency with which the society through the performance of traditional ritual acts claims responsibilities for events that in other societies take place without them."

\subsection{Boundaries and hierarchy}

One of the results of initiation is that it defines boundaries between members of a group and outsiders and also between different statuses and between contrasted ideas. The rites also involve ideas of hierarchical order, for the initiates are not only transformed, but gain status. The officiants' superiority is based on their greater ritual knowledge, and initiates are made to feel ignorant and confused to underline their inferiority (La Fontaine, 1985:17,159; Richards, 1956:72-73,74).

\subsection{Group values, group identity and social cohesion}

Initiation ceremonies can be expressive of the values of a group, but by making demands on the young, also inculcate values and enforce their maintenance. In general rites are "... invariably an effort to 'do' - to change the undesirable, or to maintain the desirable ..." (Vizedom, 1976:15-16; La Fontaine, 1985:103,33 referring to Richards (1956); quotation Richards, 1956:113; Turnbull, 1976:57-59). On the other hand, the symbols used in rituals also tend to work to make the social order acceptable to individuals.

A common ritual tradition is often seen as an important element in a community's sense of its own identity and solidarity (La Fontaine, 1985:12; Lincoln, 1981:108,93; Van der Vliet, 1976:239), but simultaneously, the mounting of an initiation ceremony does require the extensive co-operation, often with defined lines of authority most generally characteristic of a structured group. Furthermore, a degree of social pressure is required, for every adolescent must submit to some kind of ceremony (Vizedom, 1976:30; La Fontaine, 1985:121).

The social importance of transformation and social cohesion is underlined by Vizedom (1976:51) when he states:

In addition to being transformed by operation, ordeal, or learning, the person or persons being inducted often perform or participate in some action that is considered in their society a positive input into the order of things, an action that helps to make the wheels go around: he or she feeds the spirits, demonstrates that ancestral shades act through their potency or fertility, dances 
the dance that ensures perpetuation of an animal species. That is, before the ceremonies are ended, he or she has already acted in a new capacity.

\subsection{Oaths and sacred objects}

Oaths and affirmations are also commonly found in initiation rituals. A variety of acts, from a solemn oath to an act of commitment, which is not a verbal formula but merely a sign of assent to words uttered by the initiator, can be included here. This commits the individual and binds him or her to other members. Breaking such a commitment involves powerful sanctions. New commitments may be visible in a new style of dress or hair or in distinctive behaviour (La Fontaine, 1985:16). Display of some sacred objects or the practice of religion is usually an important part of societal initiation ceremonies, although these functions can in some cases lapse totally (Winick, 1957:287; Zietsman, 1972:165-6).

\section{$2.8 \quad$ Secrecy}

Secrecy is not an invariable accompaniment of initiation rites in the sense that the ritual is always performed in secret, although it often is. Yet all initiations purport to transmit knowledge and powers that are exclusive to the initiated. Some secrecy is found in all initiation rites and this is sufficient to create a barrier between people, to impede communication between those who know and those who do not. By contrast, shared secrets create a bond (La Fontaine, 1985:15;186).

It is evident how all the above influences can combine to coerce the individual to cooperate in every way. Indeed, from the viewpoint of these societies, initiation does need to be successful and is always successful and probably prepares the individual for his role in society. One has to move to a different context then, to evaluate the initiation ceremonies at universities.

\section{THE IDEA OF A UNIVERSITY}

Basic to university life is foremost the development of intellectual skills and critical thinking ability (Chickering, 1969:22,23). This goal is reached by the scientific training (education) of students and by means of research (Serfontein, 1983:69). Whilst these two are an important unity, the same unity is presupposed for the interaction between 
student and teacher. This is also clearly formulated by Venter (1987:15) when he rejects totalitarian tendencies in university life and expresses a normative definition as follows: "The university is a community of people who are interested in scientific scholarship [wetenskaplikheid] through participation in the process of science, under guidance of advanced scientists, introduced to a tradition regarding the scientific cultivation of knowledge" (my translation; cf. also Du Plessis, 1983:25,32).

\subsection{Contribution of student life to university}

The contribution students can make to a university and to intellectual and personal development, either positive or negative, should never be underestimated. Indeed, if orientation, a word commonly used at South African universities, means an insight into a total situation with a view to self-expression (Serfontein, 1983:5), one must also realize that "(a) student's most important teacher is another student. Friends and reference groups filter and modulate the messages from the larger student culture. They amplify or attenuate the force of curriculum, faculty, parietal rules, institutional regulations. They can trump the best teacher's ace and stalemate the most thoughtful or agile dean" (Chickering, 1969:253).

The question then cannot be evaded whether the role of orientation practised at some South African universities, and which is officiated over by students, makes a positive contribution to the essential activities of a university or impedes the ideals of orientation to a community of scholars. This question becomes even more pertinent when the obvious similarities between initiation in undifferentiated societies and orientation of first-years by senior students are realized. Reference can be made to the following common characteristics: the function of preparation (orientation) and social transformation; uncritical support of those in authority and the dominance of juniors by seniors; a clear liminal period during which strange actions are expected of the initiates; physical and psychological ordeals and tests; instruction with the aim of supporting the social order and authority; indicating the position and moulding the character of the initiate; restrictions placed on the initiates. Although university programmes might not include the above-mentioned, it is also possible to distinguish actions of initiation regarding "expressed purposes" and "deduced purposes" (Richards, 1956:112 et seq.).

Stroup (1964:95 et seq.) discusses the following intentions as a way of interpreting student activities systems within the university: the conformist, the anarchist and the 
ritualism philosophy. Although one might find elements of all three intentions in orientation (initiation) ceremonies, it is evident that the latter is the one which is most applicable in this instance. Ritualism, although a secondary layer of university experience, is nevertheless important because it does not always possess deliberative awareness and "... participation in ritualized behaviour by college students may be more educative (changing the person's character) in student activities than in curricular studies. In student activities such behavior truly constitutes the university's culture, and adjustment to it by students is taken as an important - sometimes controlling requirement for university. The claim is not usually made that the ritual behavior is ultimately valuable. Conformity to the developed ritual patterns may be expected or not. More likely they will be viewed as tradition, that is, simply to be accepted without rational justification, but on grounds of emotional appeal and history" (Stroup, 1964:102).

\section{THE PLACE OF INITIATION AT UNIVERSITIES}

Initiation already existed in Medieval universities and has been one of the most widespread and popular student usages in all ages. At Medieval universities, the freshman was depicted as a wild beast who had to be tamed before he was permitted to enter refined circles. He was nicknamed, chaffed and later tamed ceremonially. In the seventeenth century, a newcomer was also subjected to humiliating servitude (fagging) which "systematized all the degrading elements in previous conditions". Although some Protestant Reformers participated in the celebration of the rite (according to Luther: "This annoyance accustoms children ... to endurance ..." and to another Reformer, the aim of the ceremony was for conceited students to realize "... how trifling their learning is and how they have yet to learn ..."). It was also severely criticized because it "... gratified the bullying instinct, the social instinct, and the desire to find at once the excuse and means of a carousel". The pressure brought to bear on newcomers was such that few were able to escape this year of penal servitude (Sheldon, 1969:6;11-13).

In studying the authoritative data base ERIC extensively, the impression emerged that present initiation ceremonies still in practice at some South African universities, are not at all practised in countries like the United States. ${ }^{10}$ All assistance there is of a

\footnotetext{
10This does of course, not apply to initiation for membership of sororities and fraternities in the United States where more freedom of choice is allowed. Some changes can also be discerned at South African universities inasmuch as initiation ceremonies tend to become programmes for the orientation to university life.
} 
highly professional nature and whereas students are often involved in orientation programmes, they actually become counsellors in an official capacity. The so-called "freshman laws" by which first-year students were consigned to a form of servitude similar to the fagging of the English public schools, and which with their rigid ceremonial consigned the freshmen "to a separate and inferior caste", were in force in a number of colleges in the United States only until the opening years of the nineteenth century (Sheldon, 1969:85-87). According to Sheldon (1969:198-9; 97-102) the practice of "hazing" and "rushing" (similar to South African practices and viewed by sophomores as the only available method of disciplining conceited freshmen) were gradually disappearing in the period $1870-1900$ in the United States.

Indeed, one could argue that if one looks at the basic contents and the purpose of initiation and the idea of the university, the disappearance of initiation ceremonies seems inevitable, for:

Ritual knowledge, unlike science, is antithetical to change. It is conceived of as the property of the ancestors, the founders of all social life. It must be handed on, not tested, altered, improved or cven discarded. Since it supports experience and validates the seniority of elders, it is not surprising if they throw the weight of their secular powers behind it (La Fontaine, 1985:189).

One can also view it in another way. One of the reasons why initiation ceremonies seem like an anachronism at a university, is the conclusion of Vizedom (1976:29-30) that effecting transitions by means of ritual was most characteristic of closed rather than open ${ }^{11}$ societies.

\section{SOUTH AFRICAN UNIVERSITIES}

If the initiation ceremonies which were performed at European and American universities and which are still practised at certain South African (especially Afrikaansmedium) universities, can be interpreted in the same way as other initiation ceremonies, do they harmonize with the ideals of a university and those of the society which the university reflects? Do these initiation ceremonies aim to convey and develop the attitudes and values essential to a university to the initiates? Do they in fact prepare first-year students for their new environment and a community of scholars? It seems as if the answers to these questions tends to be negative.

"Vizedom's criteria were in the first instance exogamous unilinear descent groups that contro sources of subsistence (closed societies) and in contrast to these the multilateral/cognatic ones which are not corporate and which had social grouping for diverse purposes cross-cutting one another (open societies); cf. also La Fontaine, 1985:31. 
Do the disappearance of initiation as "total" and official ceremonies at some universities and its resilience at others in this form mirror the resistance to change in the latter universities, or perhaps the societies in which they are found? The amazing aspect and irony of this situation is that there are very strong indications that even in "undifferentiated" societies, the existence of initiation ceremonies is under attack. Keesing (1981:16) explains this phenomenon regarding initiation into male cults, as follows:

\begin{abstract}
Perhaps the rapid breakdown of initiatory cults in the last twenty years has come partly because these dogmas, ultimately cultural illusions, can no longer be sustained at all amid Toyotas and coffee, labor migration and towns and outsiders. The initiators have seen the holes in their ideologies all along, may have been led, at least at times, to see male cults and the religious dogmas that reinforce them as "what men do" ... to sustain their dominance.
\end{abstract}

If modernization has this effect on some societies, and the realization of "the holes in their ideologies" have all along been present, the resistance to change in some universities or societies must, at least in certain domains, be rigid.

\title{
6. CONCLUSIONS
}

An important matter which must be borne in mind is that, whereas most initiation ceremonies described in anthropological literature were practised in relatively undifferentiated societies, the university is part of a differentiated society yet - in some cases " $(m)$ uch of what happens to the student, particularly at the beginning and end of his university career, fits into a pattern of initiation observed by anthropologists in societies all over the world" (Whisson, 1985:2). This is important to realize because, especially in the case of initiation into a more simple and undifferentiated society as a whole, the tests and ordeals would logically have the function of a "total" preparation of a member. That is why most of these ceremonies have wide-ranging functions, including several roles expected from the individual.

In a differentiated society, several separate institutions, such as the military, the church, the political party, will each have their own and specialized ways, requirements or even ceremonies to initiate members into an organization. Each of these "initiations" will ideally have a distinguishable character and content because of the differentiated character and functions of each differentiated sphere of life. For a university this will ideally have a close association with the specific academic and intellectual activities which is the calling of scholars. It is doubtful whether this could be indicated for initiation ceremonies at South African universities. 
In undifferentiated societies one can expect a relatively unquestioning acceptance of ritual as an assertion of the authority of tradition and some degree of discrepancy between ideal and practice, where initiation is concerned. The mechanisms for criticism and change are in most cases probably limited in these societies. This, however, does not apply to a university as the epitome of modern society and its essential ability to do introspection of society and of itself and to remove anachronisms in a way which cannot reasonably be expected of some other societies.

One author (Williams, 1982:30) who ironically uses the metaphor of initiation referring to the transformation that ought to take place at universities, is in fact opposed to colleges being another pleasant link in a continuous pathway between cradle and grave. According to him "(c)ollege should be a time for short-circuiting and tearing down, for the painful and fearful experience of tumbling bodily into deep water". He views the turning out of standard products as an attack on the call to the vocation of scholarship, whereas questions on meaning, direction and purpose should be pressed with more vigour. This seems the direct opposite of the unthinking acceptance and continuance of some student practices found in South Africa.

In the anthropologist's understanding or explanation of a society and its internal relations, ritual is very significant. In as far as ritual involves moral issues, it has a definite outcome and has or seeks to have transformative capacity. It can have important symbolic or communicative effect and also is a system of control by a society or an institution (Wagner, 1984:143-145). This, without doubt, also applies to practices which initiate novices into university life and which will again have a crucial influence on society.

From a Christian view of education in general, several questions ought to be asked about the initiation practices discussed above. In many cases even Christian-educators tend to be uncritical of traditional practices because of no obvious conflict between the latter and Christian views. The conflation of several diverse functions by universities in practising initiation and the transcendence of certain boundaries of university life, is a case in point (cf. Fowler, 1990:7;131-2). It becomes clear from the above comparisons between initiation rites in undifferentiated societies and those of universities, that universities transcend the authority suitable to their office when they officialiy allow and condone students being coerced into wearing specific and usually silly uniforms, to be plunged into mudbaths and smeared with rotting and evil-smelling concoctions, to be called "snakes", "fools" and "sinews" and to be forced during their first few weeks at university, to have little and often interrupted sleep (cf. also Whisson, 1985:2), thus severely impairing their initial forays into academic endeavour. 
The aims of initiation ceremonies at universities: comparisons in time and space

\section{BIBIJOGRAPHY}

CHICKERING, A.W. 1972. Education and identity. San Francisco : Jossey-Bass. DAVIES, D. 1972. A dictionary of anthropology. London : Frederick Muller

DU PLESSIS, S.J.P. 1983. Die universiteit. Potchefstroom : PU for CHE. EDUCATIONAL Resources Information Center. Phoenix, Arizona : Oryx Press. ERIC see Educational Resources Information center.

FOWLER, S. ed. 1990. Christian schooling; education for freedom. Potchefstroom : Institute for Reformational Studies.

GEWERTZ, D.B. 1981. The father who bore me: The role of Tsambunwuro during Chambri initiation ceremonies. (In Herdt, G., ed. Rituals of manhood; male initiation in Papua New Guinea. Berkeley : Univ. of California Press. p.286-320.)

HAYS, T.E. \& HAYS, P.H. 1981. Opposition and complementarity of the sexes in Ndumba initiation. (In Herdt, G., ed. Rituals of manhood; male initiation in Papua New Guinea. Berkeley: Univ. of California Press. p.201-238.)

HERDT, G. 1981. Fetish and fantasy in Sambia initiation. (In Herdt, G. ed. Rituals of manhood: male initiation in Papua New Guinea. Berkeley : Univ. of California Press. p.44-98.)

KEESING, R.M. 1981. Introduction. (In Herdt, G. ed. Rituals of manhood; male initiation in Papua New Guinea. Berkeley : Univ. of California Press. p.1-43)

LA FONTAINE, J.S. 1985. Initiation. Middlesex : Harmondsworth.

LEVI-STRAUSS,C. 1966. The savage mind. Chicago : Univ. of Chicago Press.

LINCOLN, B. 1981. Emerging from the Chrysalis; studies in rituals of women's initiation. Cambridge : Harvard Universily Press.

NEWMAN, P.L. \& BOYD, D.J. 1981. The making of men : ritual and meaning in Awa male initiation. (In Herdt, G. ed. Rituals of manhood; male initiation in Papua New Guinca. Berkelcy : Univ. of California Press. p.239-285.)

POOLE, FJ.P. 1981. The ritual forging of identity: aspects of person and self in Bimin-Kuskusmin male initiation. (In Herdt, G. ed. Rituals of manhood; male initiation in Papua New Guinea. Berkeley : Univ. of California Press. p.99-154.)

RADCLIFFE-BROWN, A.R, 1948. The Andaman Islanders. Glencoe : Free Press.

RICHARDS, A.I. 1956. Chisungu; a girl's initiation ceremony among the Bemba of Northern Rhodesia. London : Faber \& Faber.

SCHIEFFELIN, E.L. 1981. The Bau A ceremonial hunting lodge. (In Herd, G. ed. Rituals of manhood; male initiation in Papua New Guinea. Berkeley : Univ. of California Prcss. p.155-200.)

SERFONTEIN, T. 1983. Die universiteit se taak in die orientering en inskakeling van nuweling eerstejaarstudente. Pretoria (Thesis (MA)-UP.)

SHELDON, H.D. 1969. Student life and customs. New York : Arno Press.

STROUP, H. 1964. Toward a philosophy of organized student activitics. Minncapolis : University of Minnesota.

TURNBULL, C.M. 1976. Man in Africa; Cairo to the Cape of Good Hope. New York: Anchor.

TUZIN, D.F. 1981. Ritual violence among the llahita Arapesh: the dynamics of moral and religious uncertainty. (In Herdt, G. ed. Rituals of manhood; male initiation in Papua New Guinca. Berkeley : Univ. of California Press. p.321-356.)

VAN DER VLIET, V. 1974. Growing up in traditional sociely. (In Hammond-Tooke, W.D. The Bantuspeaking peoples of Southern Africa. London : Routledge \& Kegan Paul. p.211-245.)

VAN GENNEP, A. 1960. The rites of passage. Chicago : Univ. of Chicago Press. 
VENTER, J.J. 1987. Universiteit: waarvandaan? en wat? (In Venster op die universiteit. Potchefstroom : Institute for Reformational Studies. p.1-15.)

VIZEDOM, M. 1976. Rites and relationships: rites of passage and contemporary anthropology. Beverly Hills : Sage.

WAGNER, R. 1984. Ritual as communication: Order, mcaning, and secrecy in Melanesian initiation riles. Annual Review of Anthropology, 13:143-155.

WHISSON, M. 1985. University life as an initiation rite. Rhodes Review, 5:2-3.

WILLIAMS, J.G. 1982. The ritual of initiation: implications for the liberal arts. Educational Record, 63(1):29-31.

WINICK, C. 1957. Dictionary of anthropology. London : Peter Owen.

ZIETSMAN, K. 1972. Inisiasic by die Sotho-sprekende plattelandse Bantoebevolking van Clocolan Bloemfontein. (Thesis(D.Phil.) - UOVS.) 
